Performance Evaluation of Advanced Retrofit Roof Technologies Using Field-Test Data -- Phase Three Final Report, Volume 2

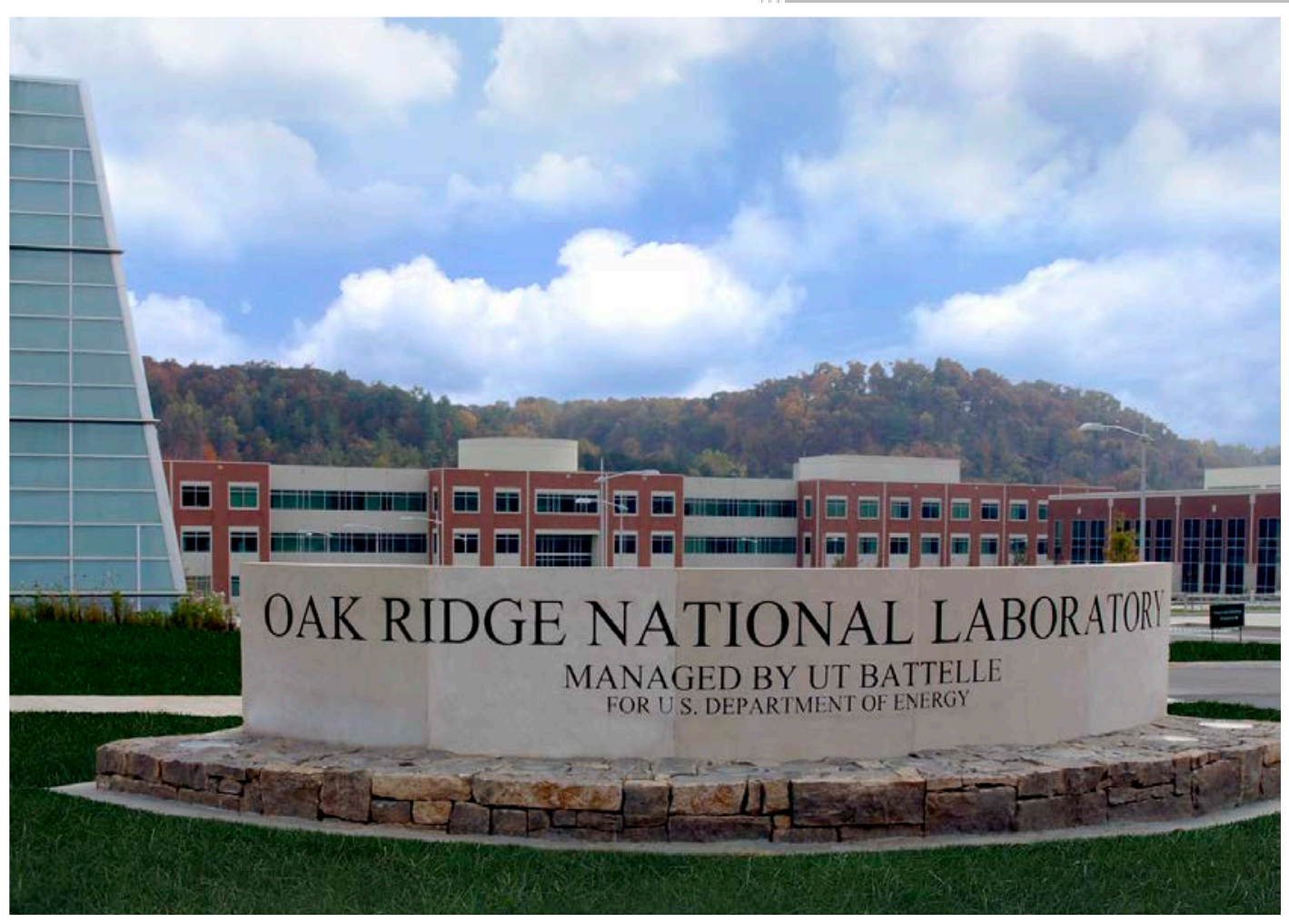

Approved for public release: distribution is unlimited.
Kaushik Biswas, Ph.D. Phillip Childs Jerald Atchley

January 2015 


\section{DOCUMENT AVAILABILITY}

Reports produced after January 1, 1996, are generally available free via US Department of Energy (DOE) SciTech Connect.

Website http://www.osti.gov/scitech/

Reports produced before January 1, 1996, may be purchased by members of the public from the following source:

National Technical Information Service

5285 Port Royal Road

Springfield, VA 22161

Telephone 703-605-6000 (1-800-553-6847)

TDD 703-487-4639

Fax 703-605-6900

E-mail info@ntis.gov

Website http://www.ntis.gov/help/ordermethods.aspx

Reports are available to DOE employees, DOE contractors, Energy Technology Data Exchange representatives, and International Nuclear Information System representatives from the following source:

Office of Scientific and Technical Information

PO Box 62

Oak Ridge, TN 37831

Telephone 865-576-8401

Fax 865-576-5728

E-mail reports@osti.gov

Website http://www.osti.gov/contact.html

This report was prepared as an account of work sponsored by an agency of the United States Government. Neither the United States Government nor any agency thereof, nor any of their employees, makes any warranty, express or implied, or assumes any legal liability or responsibility for the accuracy, completeness, or usefulness of any information, apparatus, product, or process disclosed, or represents that its use would not infringe privately owned rights. Reference herein to any specific commercial product, process, or service by trade name, trademark, manufacturer, or otherwise, does not necessarily constitute or imply its endorsement, recommendation, or favoring by the United States Government or any agency thereof. The views and opinions of authors expressed herein do not necessarily state or reflect those of the United States Government or any agency thereof. 
Energy \& Transportation Science Division

\title{
Performance Evaluation of Advanced Retrofit Roof Technologies Using Field-Test Data -- Phase Three Final Report, Volume 2
}

\author{
Kaushik Biswas \\ Phillip Childs \\ Jerald Atchley
}

Date Published: January 2015

Prepared by

OAK RIDGE NATIONAL LABORATORY

Oak Ridge, Tennessee 37831-6283

managed by

UT-BATTELLE, LLC

for the

US DEPARTMENT OF ENERGY

under contract DE-AC05-00OR22725 


\title{
Performance Evaluation of Advanced Retrofit Roof Technologies Using Field-Test Data - Phase Three Final Report, Volume 2
}

\author{
Kaushik Biswas, Ph.D. \\ Phillip Childs \\ Jerald Atchley
}

January, 2015

Notice: This report was prepared as an account of work sponsored by an agency of the United States Government. Neither the United States Government nor any agency thereof, nor any of their employees, makes any warranty, express or implied, or assumes any legal liability or responsibility for the accuracy, completeness, or usefulness of any information, apparatus, product, or process disclosed, or represents that its use would not infringe privately owned rights. Reference herein to any specific commercial product, process, or service by trade name, trademark, manufacturer, or otherwise, does not necessarily constitute or imply its endorsement, recommendation, or favoring by the United States Government or any agency thereof. The views and opinions of authors expressed herein do not necessarily state or reflect those of the United States Government or any agency thereof. 


\section{TABLE OF CONTENTS}

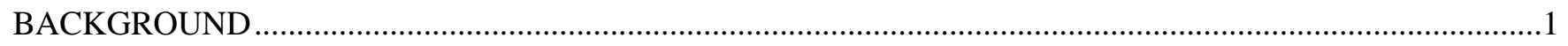

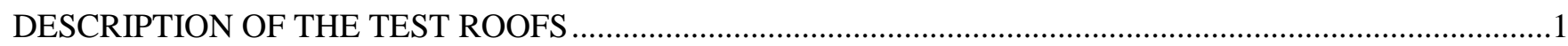

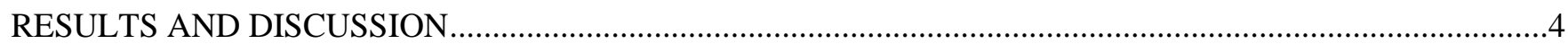

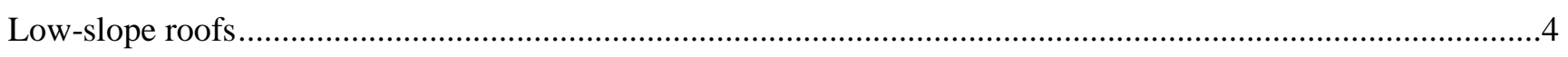

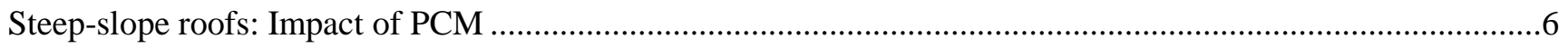

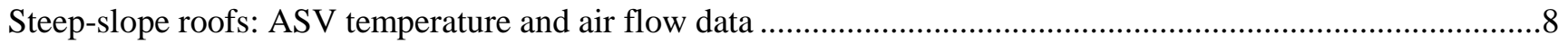

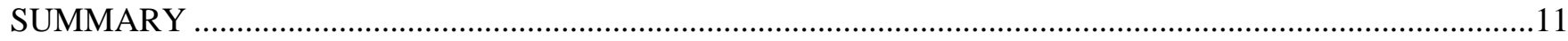

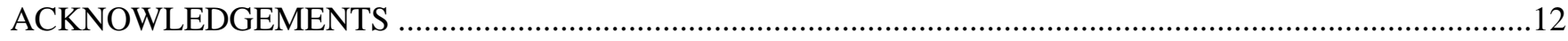

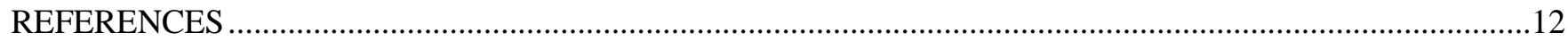




\section{BACKGROUND}

This article presents some miscellaneous data from two low-slope and two steep-slope experimental roofs. The low-slope roofs were designed to compare the performance of various roof coatings exposed to natural weatherization. The steep-slope roofs contained different combinations of phase change material, rigid insulation, low emittance surface and above-sheathing ventilation, with standing-seam metal panels on top. The steep-slope roofs were constructed on a series of adjacent attics separated at the gables using thick foam insulation.

This article describes phase three (3) of a study that began in 2009 to evaluate the energy benefits of a sustainable re-roofing technology utilizing standing-seam metal roofing panels combined with energy efficient features like above-sheathing-ventilation (ASV), phase change material (PCM) and rigid insulation board. The data from phases 1 and 2 have been previously published and reported [Kosny et al., 2011; Biswas et al., 2011; Biswas and Childs, 2012; Kosny et al., 2012]. Based on previous data analyses and discussions within the research group, additional test roofs were installed in May 2012, to test new configurations and further investigate different components of the dynamic insulation systems. Some experimental data from phase 3 testing from May 2012 to December 2013 and some EnergyPlus modeling results have been reported in volumes 1 and 3, respectively, of the final report [Biswas et al., 2014; Biswas and Bhandari, 2014].

\section{DESCRIPTION OF THE TEST ROOFS}

The low-slope test roofs were built on the Roof Thermal Research Apparatus (RTRA) in Oak Ridge, TN. The test roofs were installed on two 4 by 8 foot $\left(1.2 \times 2.4 \mathrm{~m}^{2}\right)$ modules for monitoring the surface substrate performance when exposed to the weather for extended periods. One 4 x 8 module was used to install two substrates over $4 \times 4$ foot $\left(1.2 \times 1.2 \mathrm{~m}^{2}\right)$ areas - unpainted galvalume and 'green' prepainted galvalume. On the other 4 x 8 module, white thermoplastic polyolefin (TPO) single-ply roofing membrane was installed. Both modules were covered by offset mounted crystalline photovoltaic (PV) modules. The PV outputs were not monitored.
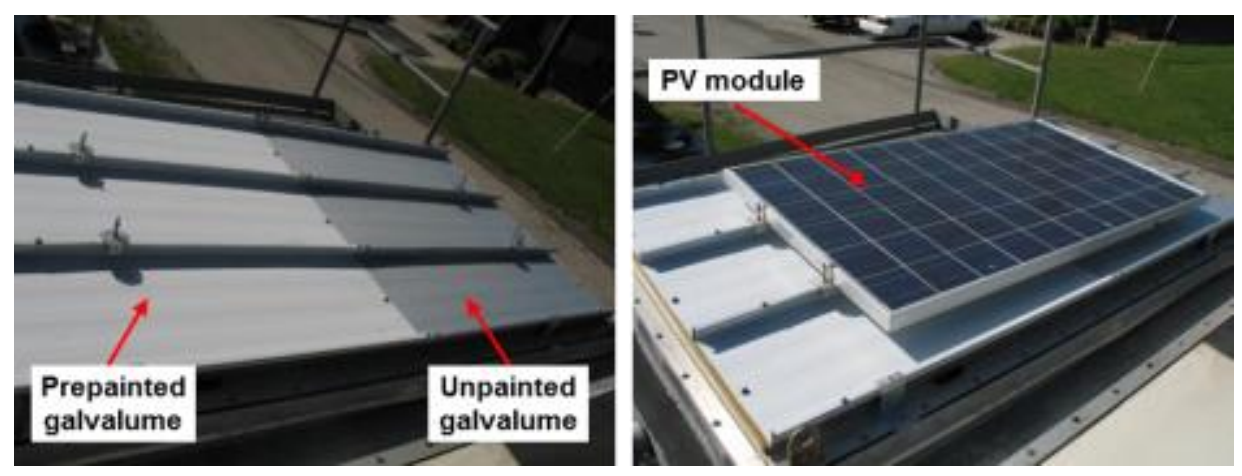

Figure 1. Low-slope test roofs: Module 1 - unpainted and prepainted galvalume. 

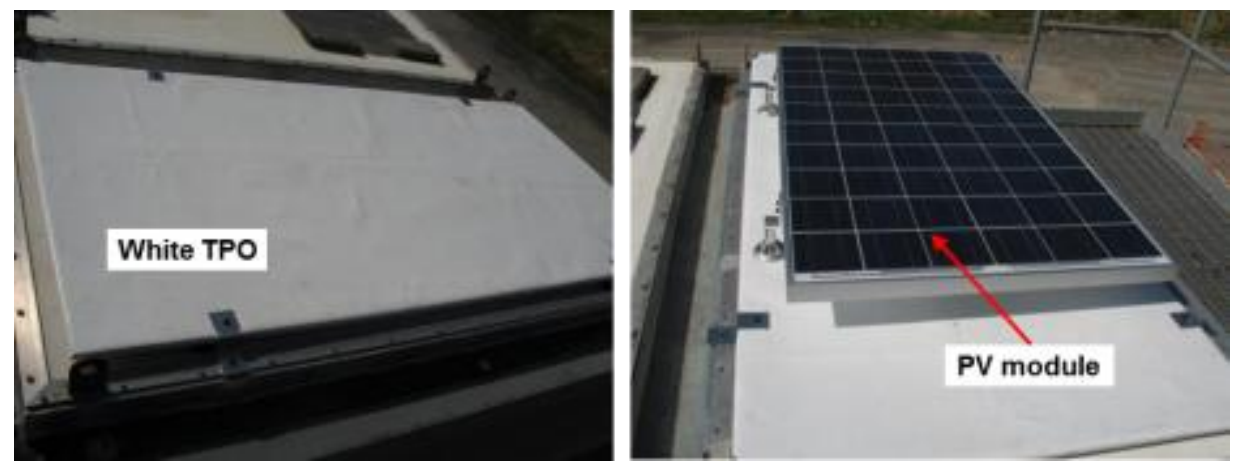

Figure 2. Low-slope test roofs: Module 2 - white thermoplastic olefin.

The steep-slope test roofs were built on side-by-side attics on the Envelope Systems Research Apparatus (ESRA) facility in Oak Ridge, TN. The attics were thermally isolated from each other by using foam insulation at the gable ends and were vented at the soffit and ridge. A conventional asphalt shingle roof was used as a control or baseline to evaluate the energy benefits of the test roofs. Further details of the attic construction are provided by Miller [2006].

Figure 3 shows the steep-slope roofs located on the ESRA. Two test roofs are described in this article and are referred to as: 'Lane 2-ASV HG' and 'Lane 4-PCM ASV'. The test roofs were built with different configurations of rigid fiberglass insulation, PCM and air gap (ASV) under the metal panels, as shown in Figure 4. Figure 4 also shows the sensors for measuring the temperature distribution in the roof and heat flow through the oriented strand board (OSB) deck into and out of the attic. 'Lane 6 - Shingle' was the control roof built with asphalt shingles [Kosny et al., 2012].
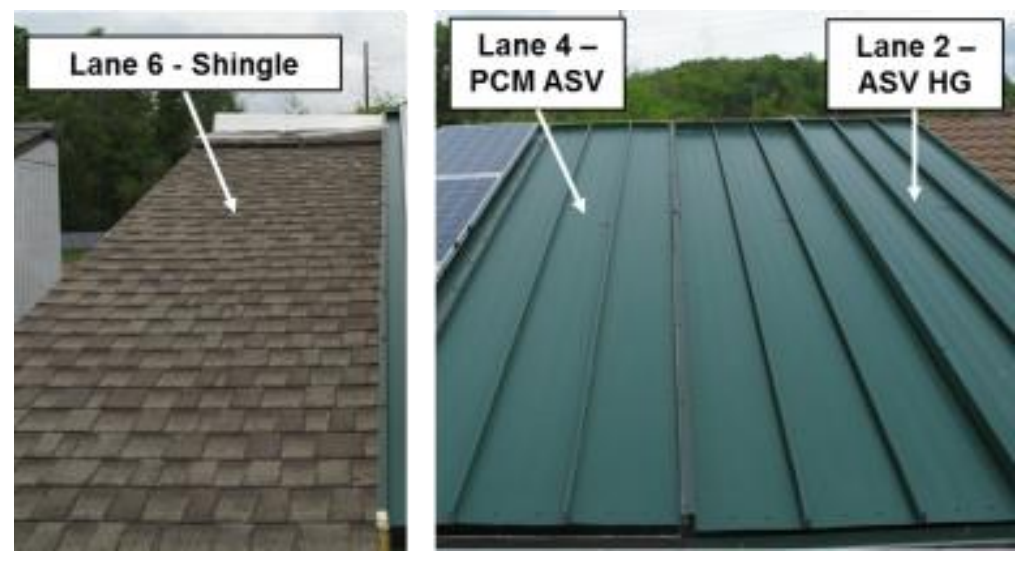

Figure 3. ESRA test and control roofs.

Lane 4 consisted of rigid fiberglass insulation on the OSB roof deck, followed by a layer of macroencapsulated bio-based PCM and the standing-seam metal panels on top. The metal panels were placed on top of metal sub-purlins that provided an air gap of about $5.1 \mathrm{~cm}(2 \mathrm{inch})$ over the PCM layer; the air gap was vented both at the ridge and the eave providing above-sheathing-ventilation (ASV). The fiberglass insulation was $2.5 \mathrm{~cm}(1 \mathrm{inch})$ thick and had a thermal resistance of $0.76 \mathrm{~m}^{2} \cdot \mathrm{K} / \mathrm{W}(4.3$ $\left.\mathrm{ft}^{2} \cdot \mathrm{hr} \cdot{ }^{\circ} \mathrm{F} / \mathrm{Btu}\right)$. The PCM was packed in arrays of plastic cells of dimensions $4.4 \mathrm{~cm} \mathrm{x} 4.4 \mathrm{~cm} \times 1.3 \mathrm{~cm}$ 
( $1.7 \times 1.7 \times 0.5$ cubic inches) with about $1.3 \mathrm{~cm}(0.5$ inch $)$ spacing between the cells. The PCM layer had nominal heat storage capacity of $560 \mathrm{~kJ} / \mathrm{m}^{2}$, and nominal melting and freezing temperatures of $30^{\circ} \mathrm{C}$ $\left(86^{\circ} \mathrm{F}\right)$ and $26^{\circ} \mathrm{C}\left(79^{\circ} \mathrm{F}\right)$, respectively. The melting phase transition enthalpy of the PCM was $190 \mathrm{~J} / \mathrm{g}$.

Lane 2 (ASV HG) roof contained the same components, but with the PCM layer placed below the fiberglass insulation. The fiberglass board in lane 2 also contained a reflective foil facing that provided a low-e surface, which reflected part of the incoming solar radiation and helped reduce daytime cooling loads. These test roofs were initially constructed in May 2012. After 9 months, in February 2013, the PCM layer was removed from lane 2, while maintaining the same ASV gap height (the original subpurlins supporting the metal panels were replaced by shorter ones).

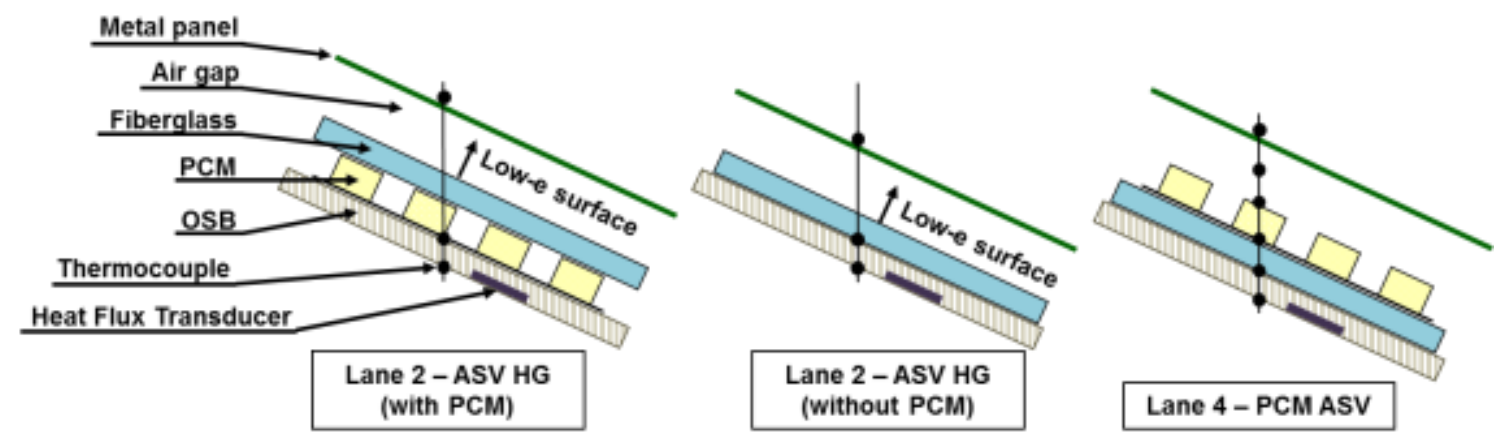

Figure 4. Schematics of steep-slope test roof configurations.

In addition to the sensors shown in Figure 4, additional thermocouples and two anemometers were installed within the air gap of lane 2 (the anemometers were added during the removal of the PCM layer). There were two thermocouples each located within the air gap near the eave and the ridge. Figure 5 shows the locations of the thermocouples and the anemometers. These sensors were added to gather data related to the air flow speed and the temperature rise within the air gap due natural convection, especially on hot and sunny summer days. 

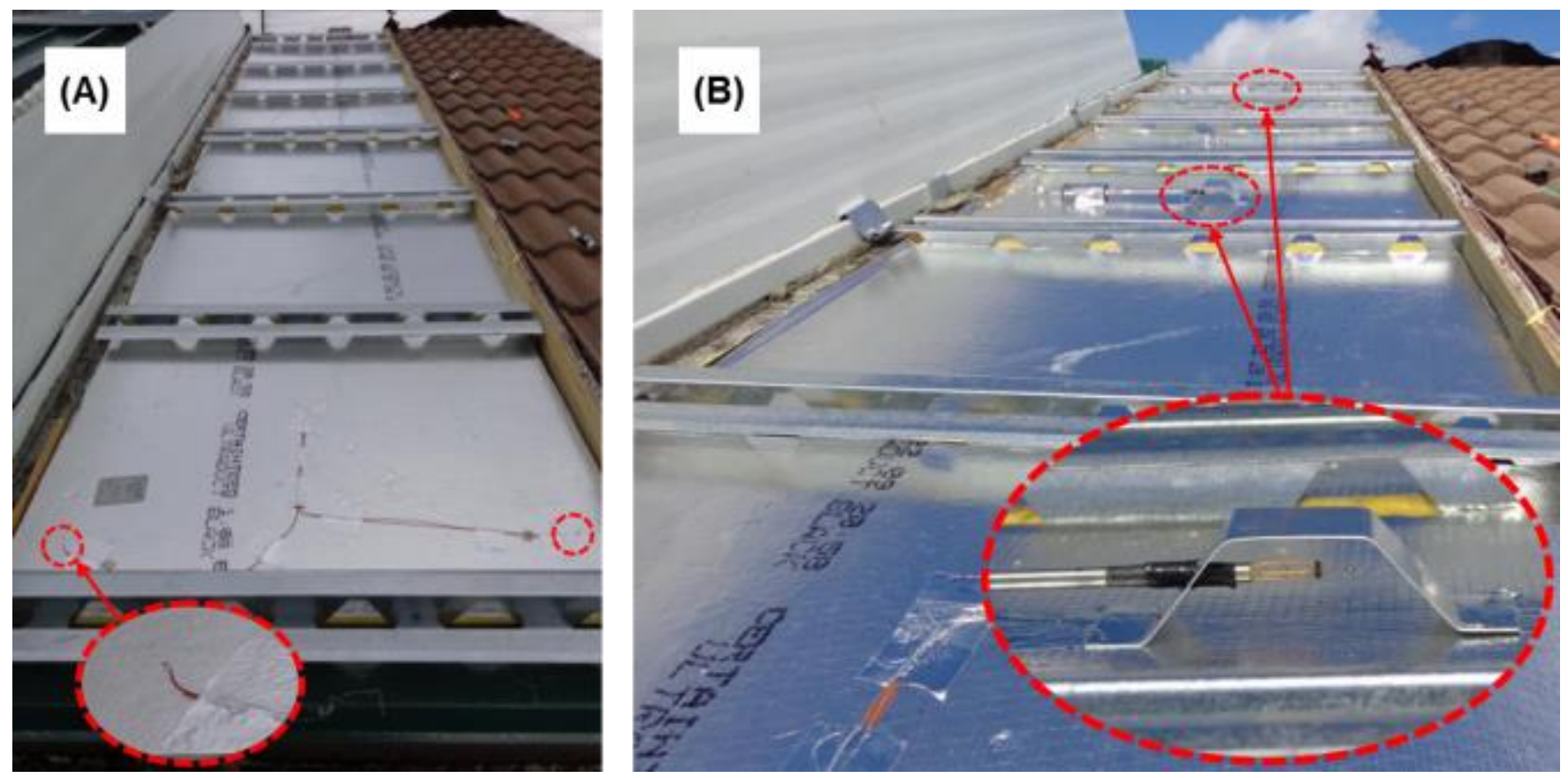

Figure 5. (a) Thermocouples within the air gap near the eave; (b) Anemometer within the air gap near the center of the roof (between the eave and the ridge) and at the ridge.

\section{RESULTS AND DISCUSSION}

\section{Low-slope roofs}

The low-slope roofs were constructed primarily to monitor degradation of the surface properties due to biological growth, soiling, etc. Figure 6-Figure 8 show the condition of the different roof membranes after about 15 months of natural weatherization since construction. All roof surfaces, unpainted and prepainted galvalume and TPO, showed some signs of surface deterioration.

Only visual inspections were performed in this study and no further analyses were done of the material deposited on the roof surfaces. However, other ORNL studies have been done related to the population of microbial species on TPO samples collected from roof modules on the RTRA. The results have been presented and published [Cheng et al., 2011; Cheng et al., 2012]. 

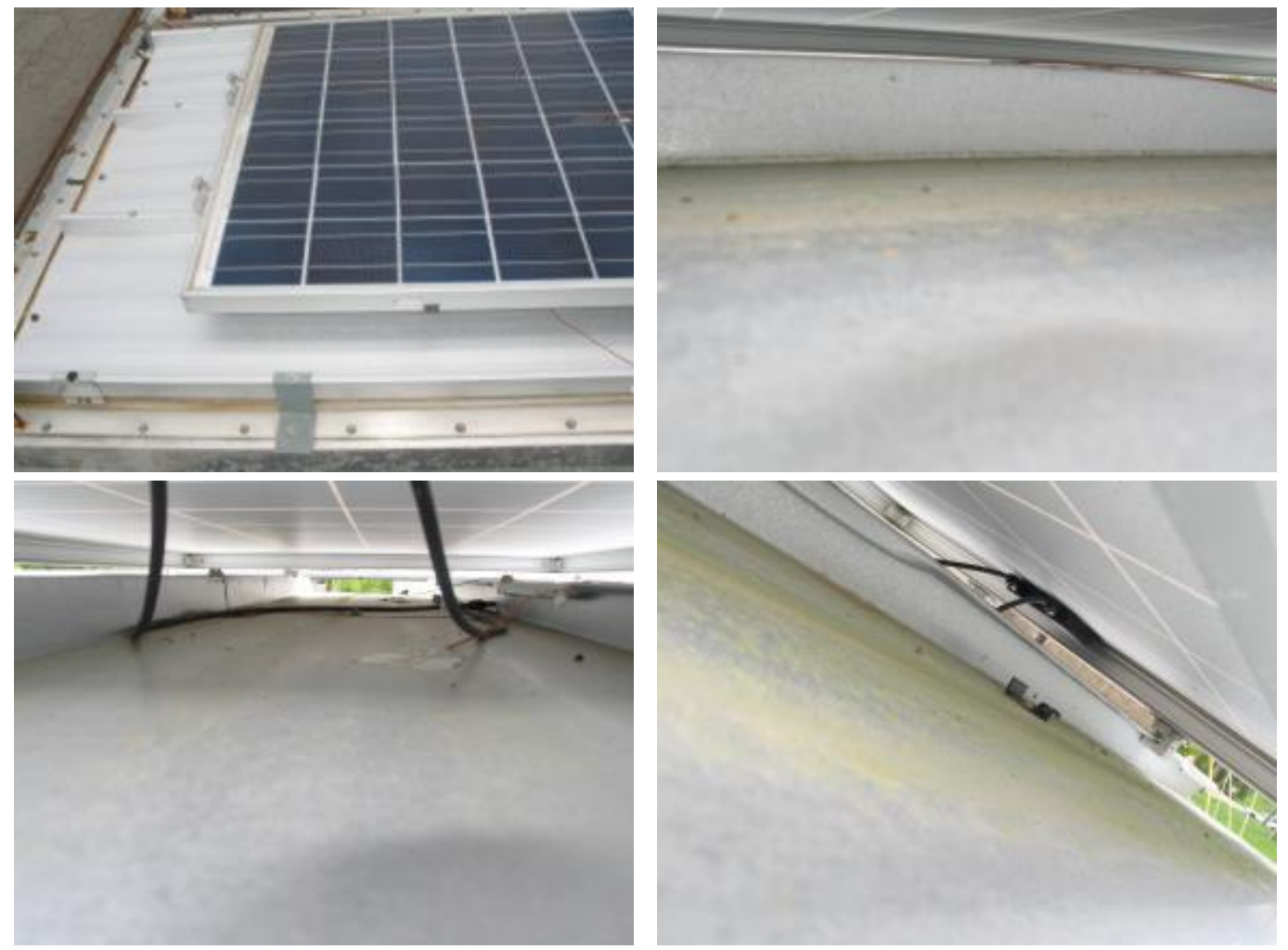

Figure 6. Surface biological growth on the roof module with unpainted galvalume.
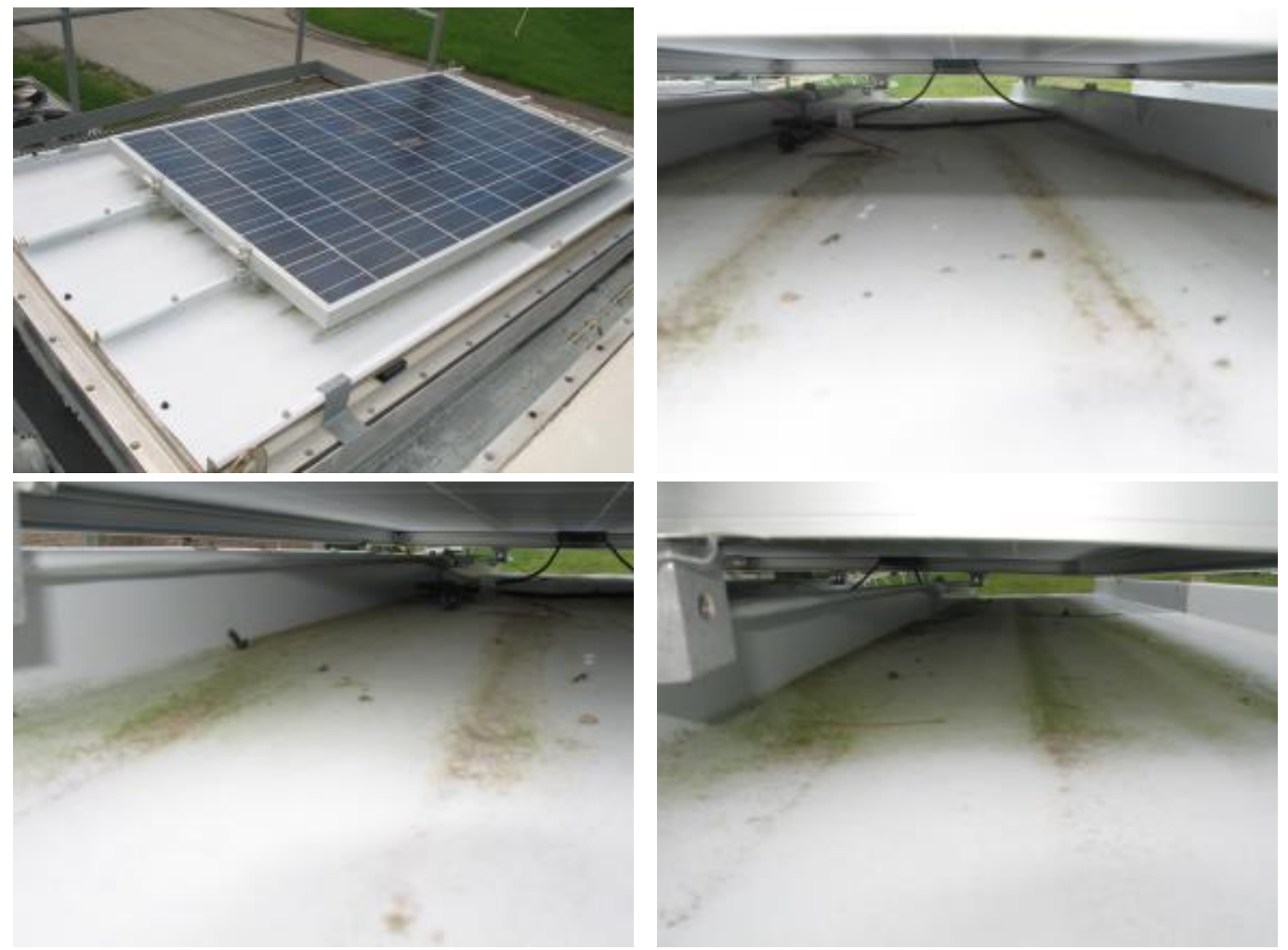

Figure 7. Surface biological growth on the roof module with prepainted galvalume. 

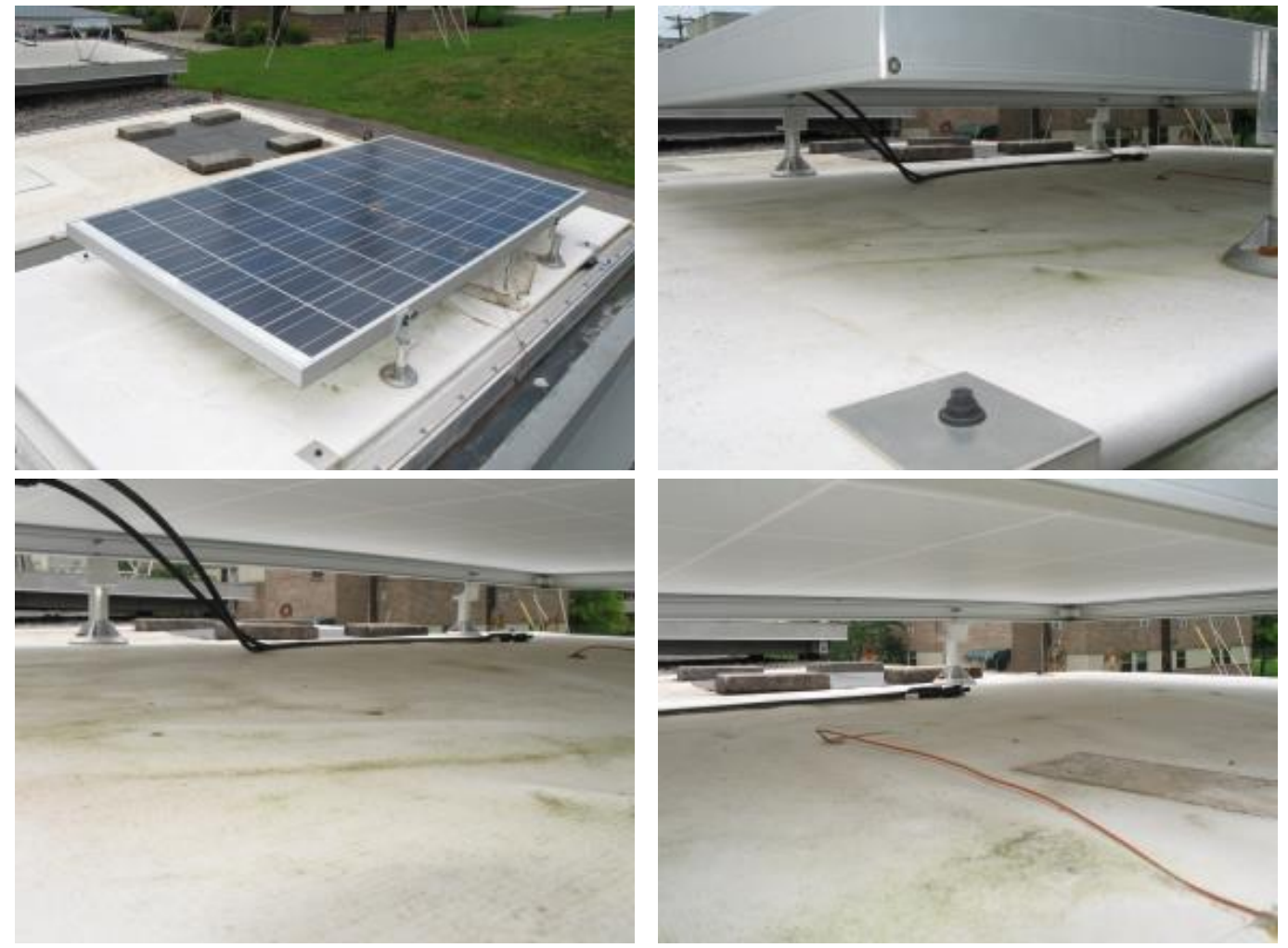

Figure 8. Surface biological growth on the roof module with TPO.

\section{Steep-slope roofs: Impact of PCM}

Summer performance: To evaluate the performance of the test roofs over the entire cooling period (summer), the roof heat fluxes and attic temperatures were averaged over June 1 - September 30, 2013. The averaging (referred to as bin-averaging) was done over corresponding 15-minute periods of each day, and the resulting average data are shown over a 24-hour period in Figure 9 and Figure 10. Further, bin-averaged solar irradiance on the roofs is shown in Figure 9 and the average outside temperature is shown in Figure 10. Data from Jun - September, 2012 (when the 'ASV HG' roof contained the PCM layer) were reported by Biswas et al. [2014], but have been repeated here for comparing the cases with and without PCM.

During summer of 2013 (wihout PCM), the peak daytime roof heat fluxes for the test and control

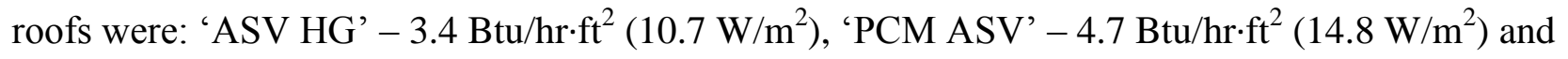
shingle $-22.2 \mathrm{Btu} / \mathrm{hr} \cdot \mathrm{ft}^{2}\left(70.0 \mathrm{~W} / \mathrm{m}^{2}\right)$. During this time, the peak average attic temperatures in the test lanes were $88.2^{\circ} \mathrm{F}\left(31.2^{\circ} \mathrm{C}\right)$ ('ASV HG') and $89.9^{\circ} \mathrm{F}\left(32.2^{\circ} \mathrm{C}\right)$ ('PCM ASV'), compared to $98.8^{\circ} \mathrm{F}$ $\left(37.1^{\circ} \mathrm{C}\right)$ in the asphalt shingle attic. A delay of about 2-2.5 hours was observed in occurrence of the peak temperature in the test attics compared to the shingle attic, which provides the benefit of peak load shifting to utilities.

During summer of 2012 (with PCM), the 'ASV HG' roof, with the PCM layer under the fiberglass insulation, performed better than the 'PCM ASV' roof. It is interesting that, even after removing the PCM layer, the 'ASV HG' roof still performed better than the 'PCM ASV' roof during summer of 2013. 
It should be noted that the 'ASV HG' roof benefitted from the low-e surface of the reflective insulation during summer. The 2013 data indicate that, at least for the present roof configurations and PCM type, the low-e surface was more effective than the PCM placed above fiberglass insulation in reducing the summer daytime roof heat gains. However, the PCM does provide an added benefit when used with the low-e surface, as shown by a comparison of the 'ASV HG' roof heat flux data between 2012 (with PCM) and 2013 (without PCM). During summer 2012, the average 'ASV HG' roof heat flux was very close to zero due to the added benefit of the PCM.
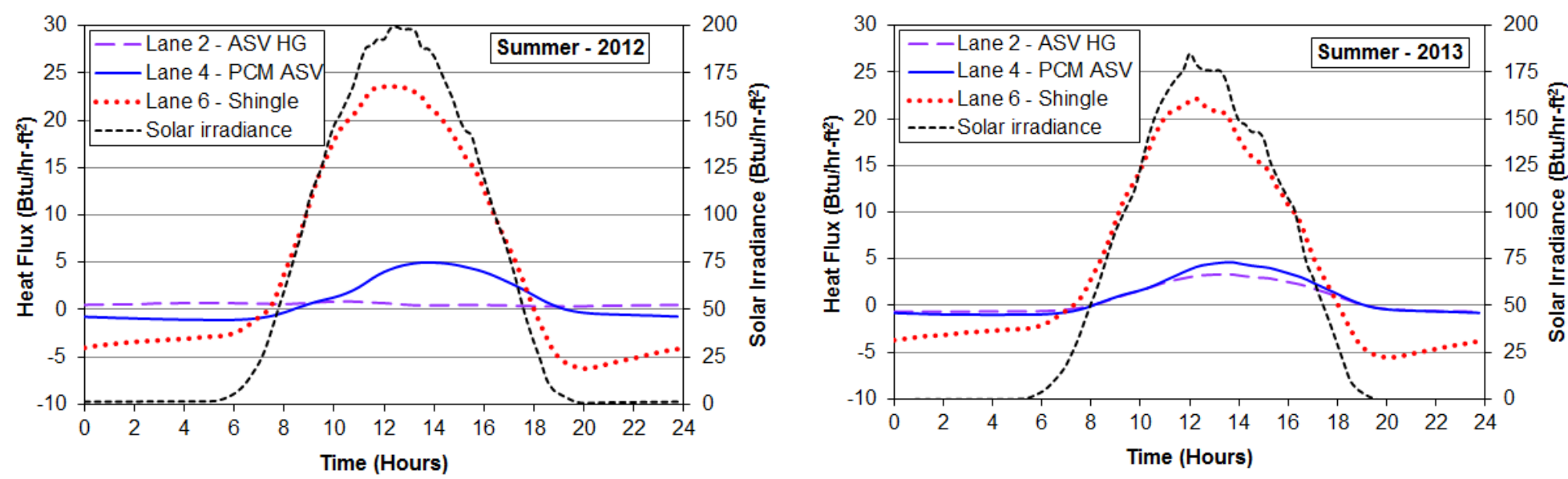

Figure 9. Bin-averaged summer roof heat fluxes.
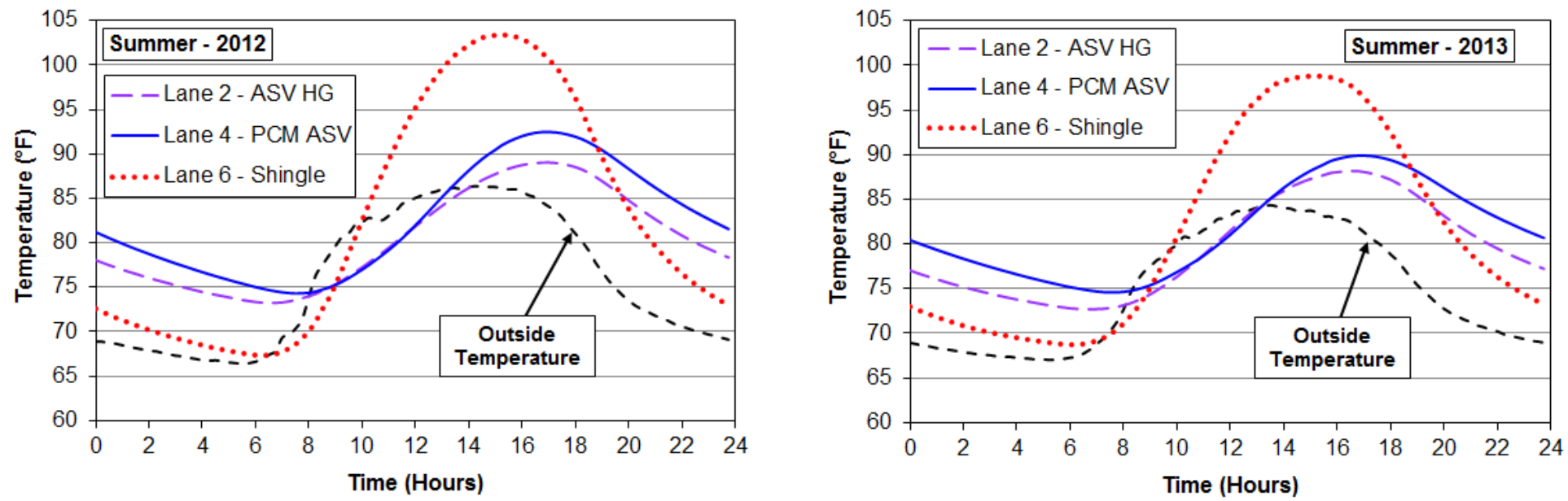

Figure 10. Bin-averaged summer attic temperatures.

Winter performance: Similar bin-averaged roof heat flux and attic temperature data are shown for winter 2013 (November 1 - December 31, 2013) in Figure 11 and Figure 12. Again, for comparison, data from winter 2012 have been reproduced [Biswas et al., 2014].

During winter, the 'PCM ASV' attic stayed warmer than the 'ASV HG' attic during both 2012 (with PCM) and 2013 (without PCM). The asphalt shingle attic had warmer daytime temperatures, due to the 
solar heat gain, but lower nighttime temperatures than the test attics. During winter 2013, the minimum average test attic temperatures were $52.0^{\circ} \mathrm{F}\left(11.1^{\circ} \mathrm{C}\right)\left({ }^{\circ} \mathrm{ASV} \mathrm{HG}\right.$ ') and $57.5^{\circ} \mathrm{F}\left(14.2^{\circ} \mathrm{C}\right)\left({ }^{\circ} \mathrm{PCM} \mathrm{ASV}\right.$ '), compared to $46.1^{\circ} \mathrm{F}\left(7.8^{\circ} \mathrm{C}\right)$ in the asphalt shingle attic. Comparison of winter 2012 and 2013 data for the 'ASV HG' lane did not reveal any significant impact of the PCM under the fiberglass insulation in that roof; it was previously reported that, for this configuration, the PCM stays frozen and inactive throughout the winter period [Biswas et al., 2011].
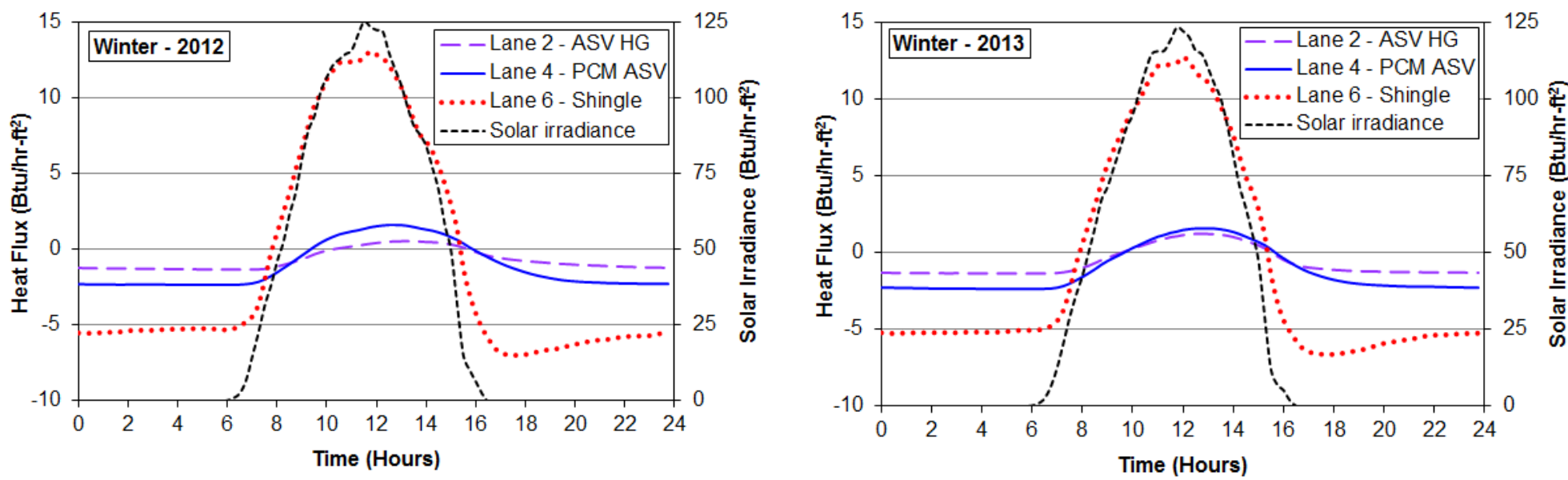

Figure 11. Bin-averaged winter roof heat fluxes.
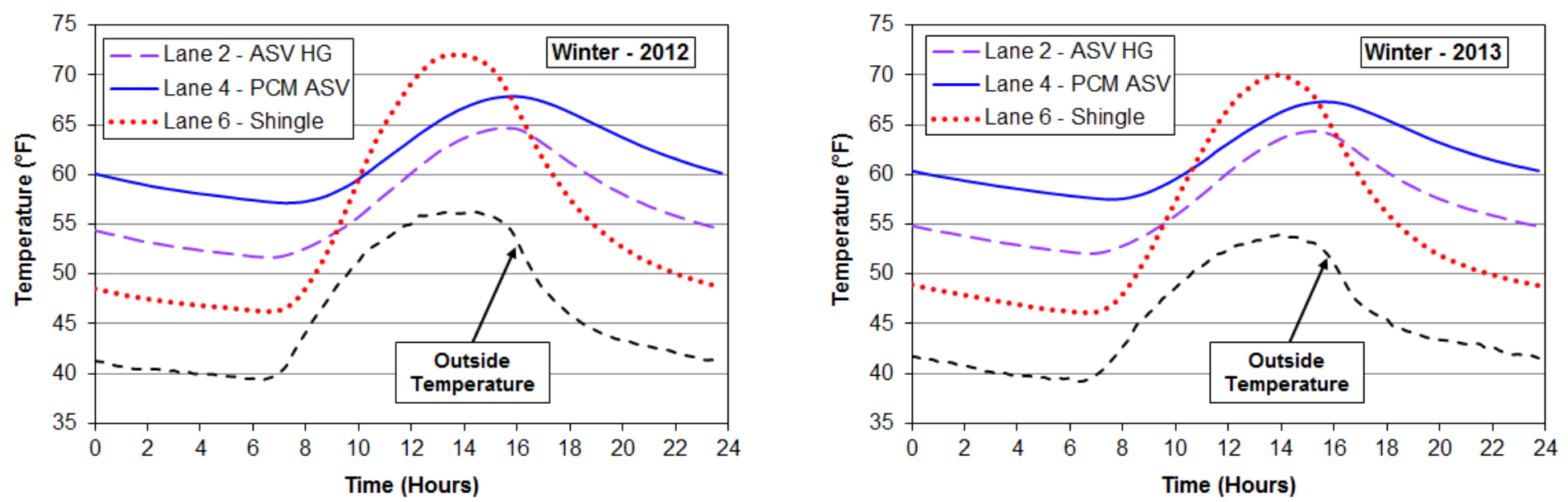

Figure 12. Bin-averaged winter attic temperatures.

\section{Steep-slope roofs: ASV temperature and air flow data}

The air-gap in the 'ASV HG' roof on lane 2 contained four thermocouples, two each near the eave and ridge, to monitor the rise in temperature of the buoyancy-driven air flow from the eave to the ridge. During February, 2013, when the PCM was removed from lane 2, two anemometers were also added to the air gap. Some sample results are shown in this section. 


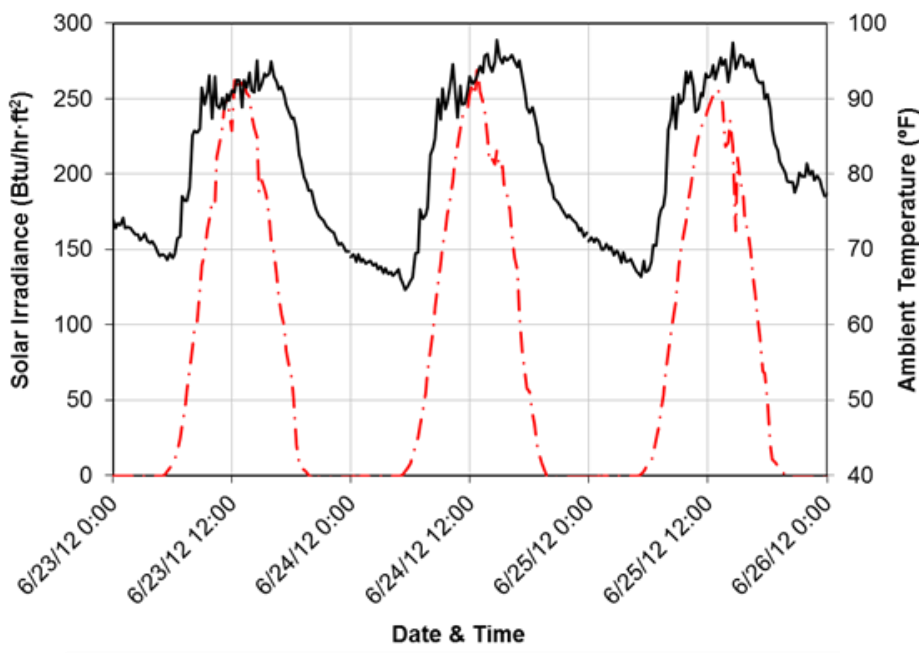

- - - Solar Irradiance _ Ambient Temperature

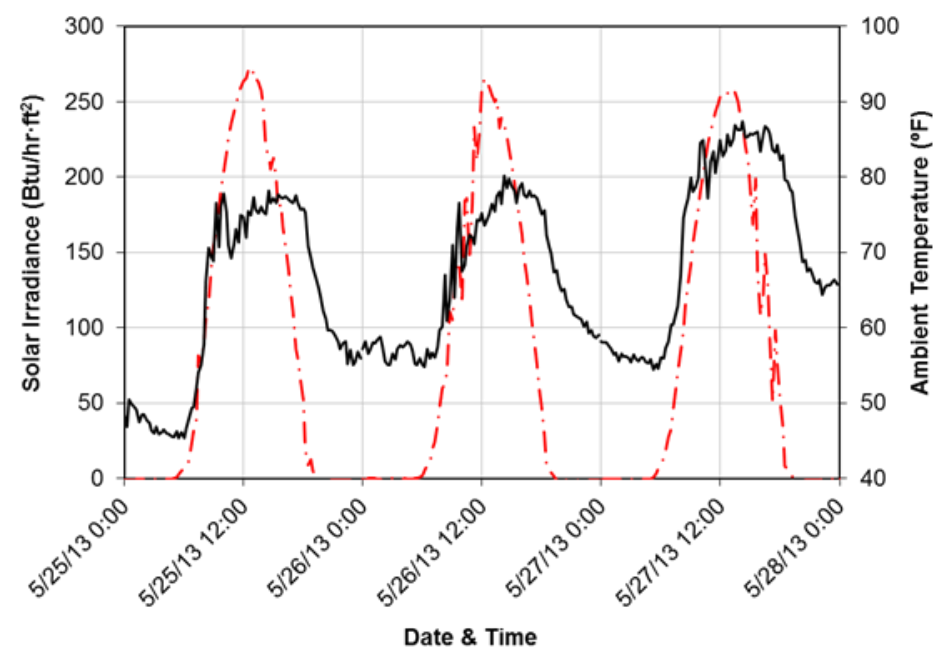

- - - Solar Irradiance

- Ambient Temperature

Figure 13. Solar irradiance and ambient temperature during three summer days from 2012 and 2013.

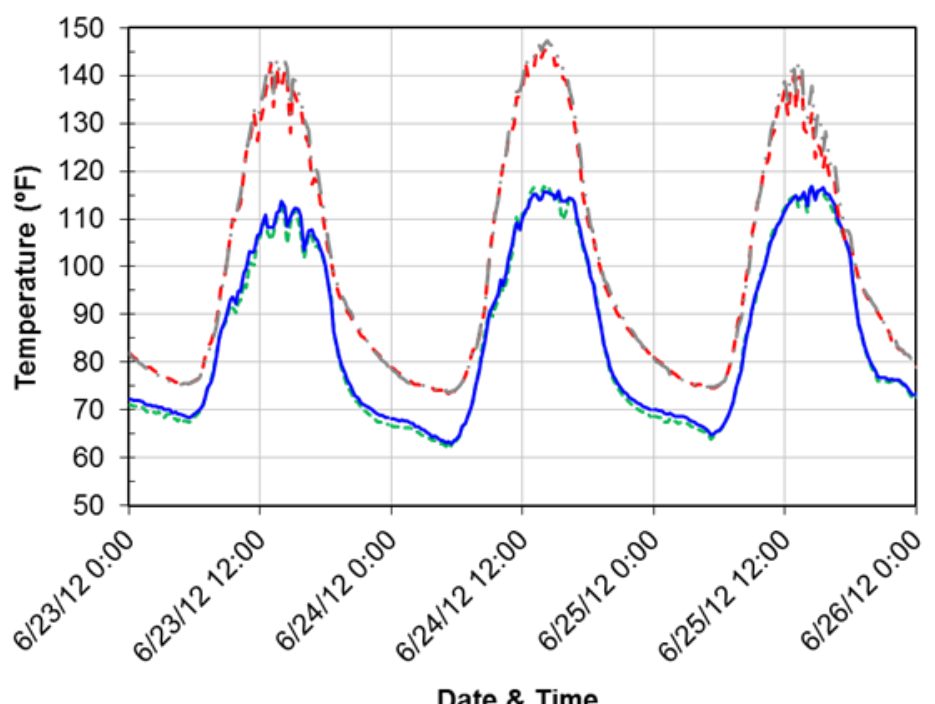

Date \& Time

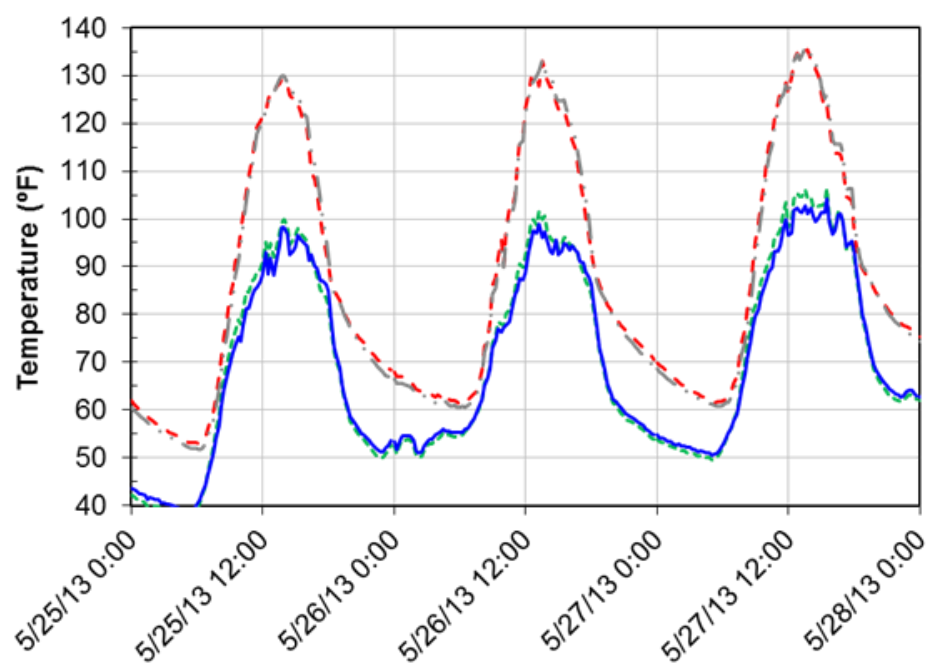

Date \& Time

----ASV HG Eave ASV W _-ASV HG Eave ASV E _ - - ASV HG Ridge ASV W - - ASV HG Ridge ASVE

Figure 14. Temperatures within the air gap in lane 2 test roof during three summer days from 2012 and 2013.

Sample summer and winter data from periods of similar solar and ambient temperature conditions from the pre- and post-PCM removal periods are presented. Figure 13 show the solar irradiance on the steep-sloped roofs and the ambient temperature from three (3) summer days in June 2012 (with PCM) and May 2013 (without PCM). The solar irradiance was similar during those two periods, but the ambient temperatures were higher during June 2012. Figure 14 shows the air gap temperature data from same 3-day summer periods. In both cases, significant rise in temperature was observed from the eave to the ridge. The measured temperatures were higher overall during the summer days of June 2012, presumably due to the higher ambient temperatures in part. The magnitudes of the increase in air 
temperatures from the eave to the ridge were similar during both periods. On average, the difference in peak temperatures at the ridge and eave during $6 / 23-6 / 26 / 2012$ was $27.9^{\circ} \mathrm{F}\left(15.5^{\circ} \mathrm{C}\right)$; during $5 / 25$ $5 / 27 / 2013$, the average difference in peak temperatures was $31.3^{\circ} \mathrm{F}\left(17.4^{\circ} \mathrm{C}\right)$.
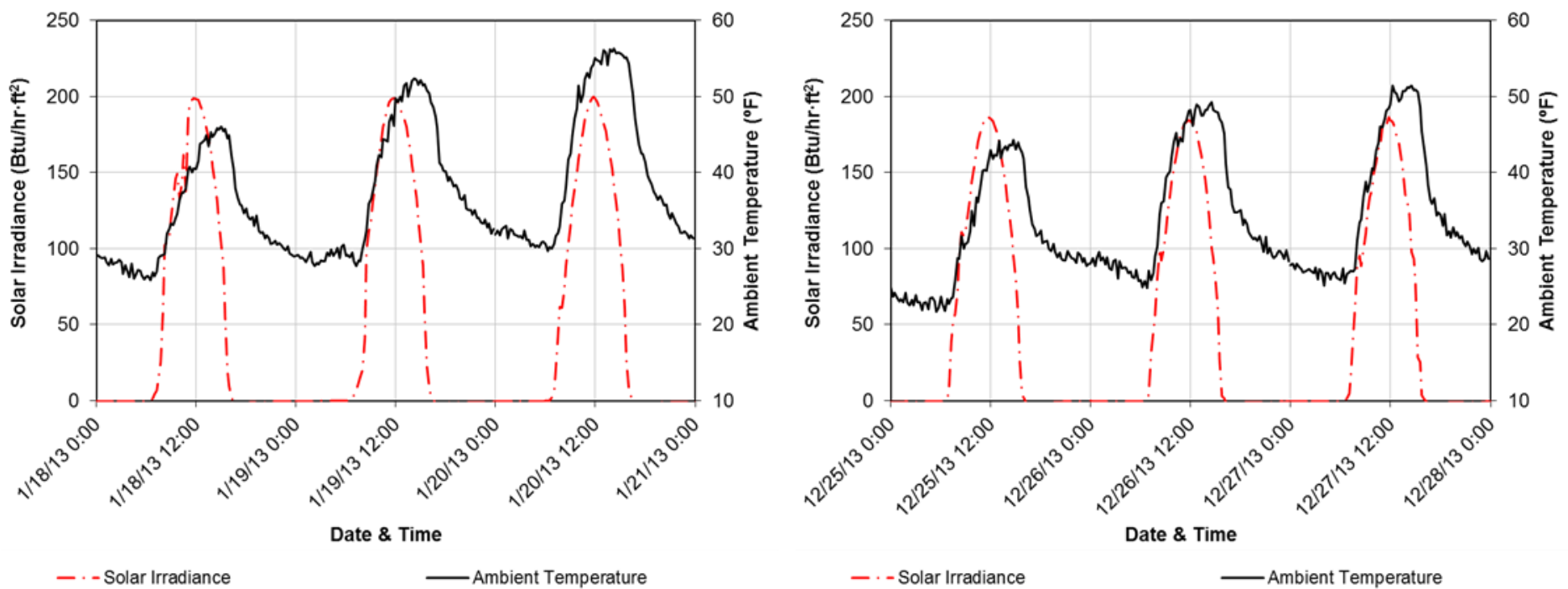

Figure 15. Solar irradiance and ambient temperature during three winter days from 2012 and 2013.
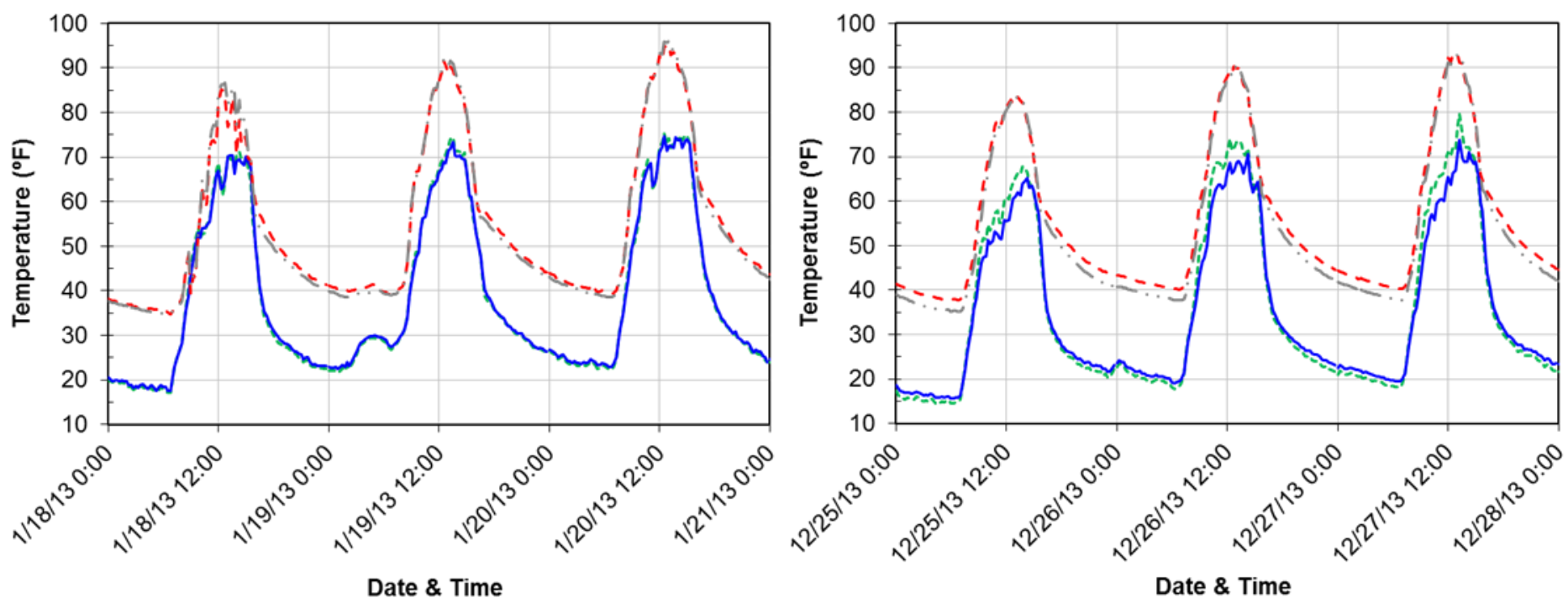

-----ASV HG Eave ASV W _ - ASV HG Eave ASV E

- - - ASV HG Ridge ASV W - - ASV HG Ridge ASV E

Figure 16. Temperature within the air gap in lane 2 test roof during three winter days from 2012 and 2013.

Similar data from three sunny winter days from the pre- and post-PCM removal periods are shown in Figure 15 and Figure 16. Again, similar increase in temperatures was observed from the eave to the ridge between the two winter periods. The average difference in peak temperatures at the ridge and eave during $1 / 18-1 / 20 / 2013$ was $17.9^{\circ} \mathrm{F}\left(9.9^{\circ} \mathrm{C}\right)$; during $12 / 25-12 / 27 / 2013$, the average difference in peak temperatures was $17.6^{\circ} \mathrm{F}\left(9.8^{\circ} \mathrm{C}\right)$. 
Figure 17 shows some sample measurements of air flow speeds from the three summer and three sunny winter days. As expected, the measured speed at the ridge was higher than the center of the roof. Also, the peak air speeds were similar for the winter and summer periods, indicating that solar irradiance, rather than ambient temperatures, was the primary driver of the buoyant air flow. The flow direction is assumed to be from the eave towards the ridge; however, anemometers used for the measurements were omni-directional and provide no information about the flow direction. Further, the anemometers provided single-point measurements of the flow speed and the data cannot reliably be used for estimating the flow rates across the entire cross-section of the air gap. The main utility of the air flow speed data was in performing validation of modeling results. These data were used for checking the intermediate results of some EnergyPlus models of the steep-slope roofs and attics. The main modeling results have been reported by Biswas and Bhandari [2014].
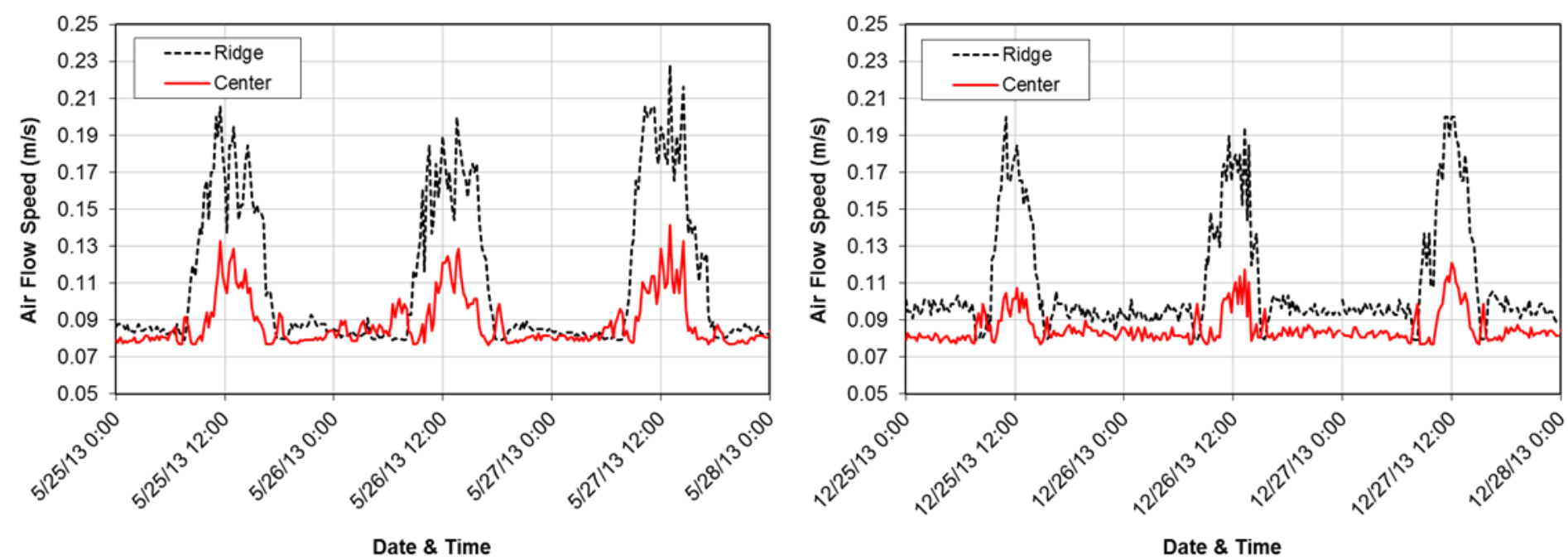

Figure 17. Measured air flow speed at two locations within the air gap in lane 2 test roof.

\section{SUMMARY}

Low-slope test roofs were constructed with three different roofing membranes: unpainted galvalume, prepainted galvalume and thermoplastic polyolefin (TPO). The low-slope roofs were designed to observe any surface deterioration of the roof coatings when exposed to natural weatherization. The lowslope roofs were covered with offset mounted photovoltaic panels. Some surface growth was observed on all the roof membranes after about 15 months of exposure.

The two steep-slope roofs, ASV HG' and 'PCM ASV' discussed in this article, contained different combinations of phase change material, rigid insulation, low emittance surface and above-sheathing ventilation, with standing-seam metal panels on top. Both test roofs were able to better modulate the attic temperatures compared to a control shingle roof. During summer, the peak day time attic temperatures were lower for the test roofs; during winter, both test attics stayed warmer than the shingle attic. The 'ASV HG' roof had the best performance during the cooling period, while the 'PCM ASV' roof performed better during the heating season. The low-e surface on the 'ASV HG' roof was very 
effective in reducing the day time heat gains through the roof, with or without the PCM. The PCM in the 'ASV HG' did show a positive impact in further reducing day time heat gains through the roof. The PCM located above the insulation in the 'PCM ASV' roof had a beneficial impact during winter, allowing the 'PCM-ASV' attic to remain warmer during the night time compared to the other roofs.

\section{ACKNOWLEDGEMENTS}

The authors would like to thank Joe Harter and Derrick Fowler (ATAS International, Inc.), Sam Yuan (CertainTeed) and Pete Horvath (Phase Change Energy Solutions) for their contributions.

\section{REFERENCES}

1. Biswas, K., Miller, W., Childs, P., Kosny, J. and Kriner, S. 2011. Performance Evaluation of a Sustainable and Energy Efficient Re-Roofing Technology Using Field-Test Data. Proceedings of the 2011 NRCA International Roofing Symposium, Washington D.C., September 2011.

2. Biswas, K. and P. Childs. 2012. Performance Evaluation of Advanced Retrofit Roof Technologies Using Field-Test Data - Phase Two Final Report. ORNL/TM-2012/23. Oak Ridge, TN.

3. Biswas, K., Childs, P. and Atchley, J. 2014. Performance Evaluation of Advanced Retrofit Roof Technologies Using Field-Test Data - Phase Three Final Report, Volume 1. ORNL/TM2014/141. Oak Ridge, TN.

4. Biswas, K., and Bhandari, M. 2014. Performance Evaluation of Advanced Retrofit Roof Technologies Using Field-Test Data - Phase Three Final Report, Volume 2. ORNL/TM2014/256. Oak Ridge, TN.

5. Cheng K.R., Pfiffner S.M., Cheng M-D., and Desjarlais A.O. 2012. Bio-geographical survey of biofouling microbial communities on naturally weathered cool roof materials. Presented at the American Society for Microbiology General Meeting, June 2012 in San Francisco, CA.

6. Cheng M-D., Pfiffner S.M., Miller W.A., and Berdahl P. 2011. Chemical and microbial effects of atmospheric particles on the performance of steep-slope roofing materials. Building and Environment, 46:999-1010.

7. Kosny, J., Biswas, K., Miller, W., Childs, P., and S. Kriner. 2011. Sustainable Retrofit of Residential Roofs Using Metal Roofing Panels, Thin-Film Photovoltaic Laminates and PCM Heat Sink Technology. Journal of Building Enclosure Design, National Institute of Building Sciences, Building Enclosure Technology and Environment Council (BETEC), Winter 2011/3.

8. Kosny J., Biswas K., Miller W., and S. Kriner. 2012. Field Thermal Performance of Naturally Ventilated Solar Roof with PCM Heat Sink. Solar Energy, 86:2504-2514.

9. Miller, W. A. 2006. The Effects of Infrared-Blocking Pigments and Deck Venting on StoneCoated Metal Residential Roofs. ORNL/TM-2006/9. Oak Ridge, TN.

10. Miller, W. A. and J. Kosny. 2007. Next Generation Roofs and Attics for Residential Homes. Proceedings of the 2007 ACEEE Summer Studies on Energy Efficiency, August 2007, Pebble Beach, California. 